\title{
Histopathology of the mangrove land crab Ucides cordatus (Ocypodidae) affected by lethargic crab disease
}

\author{
Walter A. Boeger ${ }^{1,2, *}$, Marcio R. Pie ${ }^{1,2}$, Vânia Vicente ${ }^{2,3}$, Antonio Ostrensky ${ }^{2,4}$, \\ Diogo Hungria ${ }^{1,2}$, Gisela G. Castilho ${ }^{2}$
}

\author{
${ }^{1}$ Laboratório de Ecologia Molecular e Parasitologia Evolutiva, Departamento de Zoologia, \\ ${ }^{2}$ Grupo Integrado de Aqüicultura e Estudos Ambientais, ${ }^{3}$ Departamento de Patologia Básica, and \\ ${ }^{4}$ Departamento de Zootecnia, Universidade Federal do Paraná, Caixa Postal 19073, CEP 81531-990, Curitiba, PR, Brazil
}

\begin{abstract}
Lethargic crab disease (LCD) has caused extensive epizootic mortality of the mangrove land crab Ucides cordatus (Linnaeus 1763) (Brachyura: Ocypodidae) along the Brazilian coast. Direct culture of tissue samples from sick crabs and subsequent isolation and purification identified the causative agent as an Exophiala species of fungus. The histopathology of crabs with variable signs of LCD indicates that the most affected tissues are the epidermis, connective tissue, heart, hepatopancreas, nervous system, and gills. Gonads, somatic muscles, and digestive system are less affected by the fungus. The observed pathology is compatible with the clinical signs of LCD. Necrosis, tissue degeneration, and congestion of hemal sinuses and vessels are present in heavily infected organs. Nerve fibers may be compressed by accumulations of yeast-like cells. In heavy infections the tissue of gill lamellae is destroyed with subsequent dilation or compression. Cellular immune responses include hemocytic infiltration, agglutination and encapsulation, and phagocytosis. Phagocytosis of yeast-like cells is abundant in the connective tissue associated with the exoskeleton. These results indicate that LCD is the result of a systemic phaeohyphomycosis caused by a species of Exophiala. The present study also suggests that dispersal of the fungus within the crab occurs through the hemal system.
\end{abstract}

KEY WORDS: Histopathology $\cdot$ Lethargic crab disease $\cdot$ LCD $\cdot$ Mangrove land crab · Ucides cordatus Exophiala sp. S Systemic phaeohyphomycosis

\section{INTRODUCTION}

Lethargic crab disease (LCD) has caused extensive epizootic mortality of the mangrove land crab Ucides cordatus (Linnaeus 1763) (Brachyura: Ocypodidae) along the Brazilian coast (Boeger et al. 2005). No similar mortalities have been reported in the scientific literature for this species elsewhere in the world. Since the disease was first reported in 1997, near the city of Goiana, State of Pernambuco, it has spread northward and southward, affecting populations of $U$. cordatus in the states of Ceará, Rio Grande do Norte, Paraíba, Pernambuco, Alagoas, Sergipe, Bahia, and Espírito Santo.
The ecological and economic impacts of LCD are extensive. The mangrove land crab is considered a keystone species of West Atlantic mangroves, being responsible for the consumption and subsequent degradation of more than half of the leaf litter in these environments (Schories et al. 2003). In addition, this species represents an important fishery resource for local communities along the Brazilian coast. For instance, according to a survey of 21 fishing communities located in the region of the Caeté estuary (State of Pará, Northern Brazil), mangrove land crab is collected and sold by $42 \%$ of the households, and constitutes a main source of income for $38 \%$ of them (Glaser 2003). 
LCD can significantly reduce the commercial landings of this crab species. Reductions in fishing yields were reported as 84 and $97.6 \%$ in mangroves in Paraíba and Bahia, respectively (Nóbrega \& Nishida 2003, Schmidt 2006). The main signs of LCD include increasingly weak motor control, particularly of pereiopods and chelae, causing lethargy and poor balance, followed by the death of the affected crab. Fishermen have reported that tetany is also observed in many crabs with LCD. During outbreaks of this disease, most dead crabs are found outside of their burrows (Schmidt 2006).

Several potential etiological agents for LCD have been anecdotally proposed over the years, including viruses, bacteria, environmental pollution, and substances used in shrimp culture and other industries. However, the only scientific study to address the cause of LCD was reported by Boeger et al. (2005), where evidence from a variety of sources (light and electron microscopy, behavioral tests, and molecular phylogenetics) indicated that LCD is associated with the presence of dematiaceous fungus of the family Herpothrichiellacea.

A fundamental step toward a better understanding of LCD is to describe the manifestation of the disease and the pathology caused by the agent. In this study we describe the histopathological consequences of LCD in individuals captured in the wild during outbreaks of the disease. We show that the clinical signs of LCD are closely associated with the presence of yeastlike cells and, to a minor extent, of hyphae, resulting in tissue lesions and cellular responses.

\section{MATERIALS AND METHODS}

Moribund mangrove land crabs with varying signs of LCD and apparently healthy animals were captured from the states of Sergipe and Bahia, Brazil, by professional fishermen during outbreaks of the disease in 2004 and 2005 (Table 1). The animals from Sergipe were immediately submitted to a test designed to evaluate their health status (Health Index). This test was performed by turning each individual crab upside down and measuring the time (in seconds) until their return to the upright position (Table 2). If the crab was unable to recover after more than $30 \mathrm{~s}$, a value of $999 \mathrm{~s}$ was arbitrarily assigned. The mean of 5 repetitions of this procedure was used in the establishment of the Health Index. Dead crabs were not collected.
Crabs were euthanized in iced freshwater and tissues were immediately removed and fixed in Davidson's AFA (alcohol, formalin, acetic acid) (Humason 1979) and stored in $70 \%$ ethanol. Epidermis, hepatopancreas, heart, gills, thoracic ganglion, intestine, gonads, and somatic muscle were processed for histological examination using standard protocols. Sections of $5 \mu \mathrm{m}$ thickness were prepared using a rotary microtome (Leica RM2125RT) and stained with Harris' haematoxylin and eosin ( $\mathrm{H} \& \mathrm{E})$, periodic acid Schiff (PAS), Mallory's trichrome, or Grocott's gethanamine silver (GMS) (Humason 1979). Processed sections were examined under standard light microscopy (Olympus BX 51) and photographed with a QColor 5 digital camera. Magnification scales were added with the software Image J (Rasband 2006).

For ultrastructural analyses, small samples of tissue (about $2 \mathrm{~mm}^{3}$ ) were removed and fixed in $2 \%$ gluteraldehyde for $3 \mathrm{~h}$ and stored in a sucrose-cacodylate buffer solution ( $\mathrm{pH} 7.4$ ). Tissues were post-fixed in $2 \%$ osmium tetroxide for $4 \mathrm{~h}$, washed in $0.1 \mathrm{M}$ sodium cacodylate buffer, dehydrated in an ethanol series, and embedded in resin (Embed $812^{\circledR}$ ). Ultrathin sections (70 to $90 \mathrm{~nm}$ ) were mounted on copper grids, stained with uranyl acetate and observed and photographed with a JEOL JEM 1200 EXII transmission electron microscope.

Samples of infected tissues of moribund crabs (heart, hepatopancreas, thoracic ganglion, and hemolymph) were inoculated in Agar-Mycosel medium (de Hoog et al. 2003) and incubated at $36^{\circ} \mathrm{C}$ for $20 \mathrm{~d}$. After isolation and purification, the fungus was identified based on its macro- and microscopic morphology using light microscopy.

\section{RESULTS}

Direct culture from all sampled tissues of moribund crabs resulted in the isolation and purification of a black yeast, a species of Exophiala (Ascomycota; Pezizomycotina; Herpotrichiellaceae) (Fig. 1). This species

Table 1. Ucides cordatus. Localities and dates of collection of mangrove land crabs exhibiting signs of lethargic crab disease, and the respective number of sampled specimens (N). BA: state of Bahia; SE: state of Sergipe

\begin{tabular}{|lrrrr|}
\hline Locality & \multicolumn{2}{c}{ Coordinates } & Date & $\mathrm{N}$ \\
\hline Garapuá (BA) & $13^{\circ} 28^{\prime} 50^{\prime \prime} \mathrm{S}$, & $38^{\circ} 54^{\prime} 50^{\prime \prime} \mathrm{W}$ & Feb 2004 & 12 \\
Brejão (SE) & $10^{\circ} 31^{\prime} 56.9^{\prime \prime} \mathrm{S}$, & $36^{\circ} 29^{\prime} 27.1^{\prime \prime} \mathrm{W}$ & May 2004 & 6 \\
Brejão (SE) & $10^{\circ} 32^{\prime} 14.7^{\prime \prime} \mathrm{S}$, & $36^{\circ} 30^{\prime} 44.9^{\prime \prime} \mathrm{W}$ & May 2004 & 6 \\
Areia Branca (SE) & $11^{\circ} 03^{\prime} 46.1^{\prime \prime} \mathrm{S}$, & $37^{\circ} 08^{\prime} 17.8^{\prime \prime} \mathrm{W}$ & May 2004 & 4 \\
Crastro (SE) & $11^{\circ} 25^{\prime} 02.2^{\prime \prime} \mathrm{S}$, & $37^{\circ} 24^{\prime} 52.6^{\prime \prime} \mathrm{W}$ & May 2004 & 5 \\
Taiçoca de Fora (SE) & $11^{\circ} 25^{\prime} 02.1^{\prime \prime} \mathrm{S}$, & $37^{\circ} 24^{\prime} 52.7^{\prime \prime} \mathrm{W}$ & May 2004 & 4 \\
Caravelas (BA) & $1^{\circ} 42^{\prime} 59^{\prime \prime} \mathrm{S}$, & $39^{\circ} 18^{\prime} 25^{\prime \prime} \mathrm{W}$ & Feb 2005 & 34 \\
\hline
\end{tabular}


Table 2. Ucides cordatus. Average time needed to return to the upright position during behavioural test, classification according to the Health Index (see Table 3), and number of crabs $(\mathrm{N})$ detected within each category (see 'Materials and methods' for details)

\begin{tabular}{|lcc|}
\hline Avg. time (s) & Description & $\mathrm{N}$ \\
\hline $0-3$ & Healthy & 7 \\
$3-5$ & Intermediate & 5 \\
$5-300$ & Sick & 2 \\
$300-999$ & Moribund & 5 \\
\hline
\end{tabular}

is characterized by a near absence of yeast cells in culture; its conidiophores are short, erect, brown, cylindrical, and multi-celled; its conidia are 0 to $1 \mathrm{sep}$ tate and obovoidal to cylindrical, and chains of barrel shaped hyphal cells (tolurose hyphal) may be present. Morphology of the fungus within the tissue of Ucides cordatus is consistent with this identification. The species is likely new and efforts are presently under way to provide a formal description of the pathogen (in collaboration with S. C. de Hoog, Centraalbureau voor Schimmelcultures, Netherlands). Experimental and molecular evidence (W. A. Boeger and collaborators unpubl. data) suggest that the species is the agent responsible for LCD.

Although yeast cells (Fig. 2A-F), conidia (Fig. 2D) (both cell types are called here yeast-like cells), and hyphae (Figs. 2G \& 4A) were widely distributed within the body of LCD-infected crabs, the degree of damage caused by the fungus varied according to the tissue and the fungal form present. The fungus was detected in the tissue and or the hemal lacunae of the epidermis, connective tissue, hepatopancreas, heart, thoracic ganglion and associated nerve fibers, gills, and intestine. The tissue of the gonads and the somatic musculature were apparently free of the fungus in the crabs studied. A synthesis of the pathologies associated with the general health state of the crab is presented in Table 3.

In general, the presence of yeast-like cells was associated with more extensive lesions than those observed when hyphae are the most prevalent form in the tissue. Histopathological characterization of each examined tissue or organ is provided below.

\section{Epidermis and connective tissue associated with the exoskeleton}

Crabs with LCD showed a great accumulation of yeast-like cells in the interstitial spaces of the epidermal and connective tissues associated with the exoskeleton. Reserve-inclusion cells (RI cells) bearing a large number of yeast-like cells were abundant within the epidermis and connective tissue of moribund crabs (Fig. 2A,B). Within these cells, no large digestive vacuoles were observed, except for a hyaline area involving each yeast-like cell, suggesting the presence of small individual vacuoles. Phagocytic cells (Figs. 2A,C \& 3) and melanized and non-melanized hemocytic encapsulations (Fig. 2A) were present in the connective tissue in advanced stages of infection. The phagocytes were engorged with large numbers of yeast-like cells, located in a large internal vacuole (Fig. 2A,C). These phagocytic cells most likely represent hemocytes that infiltrated the connective tissue from the hemolymph. These cells appear to
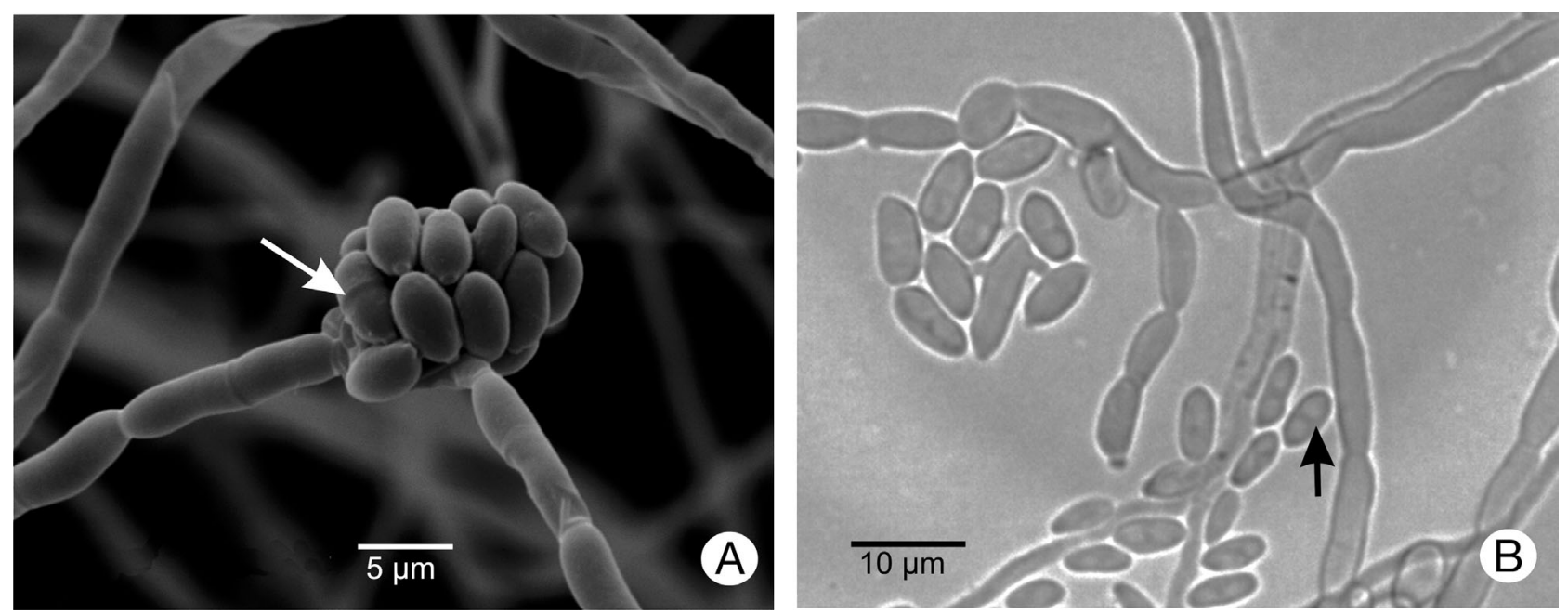

Fig. 1. Exophiala sp. isolated from Ucides cordatus showing signs of the lethargic crab disease. (A) Scanning electron micrograph of a conidial apparatus and hyphae of Exophiala sp. Arrow points to a conidium with external evidence of septum. (B) Light microscopy micrograph of conidia, many evidencing internal septum (arrow) 

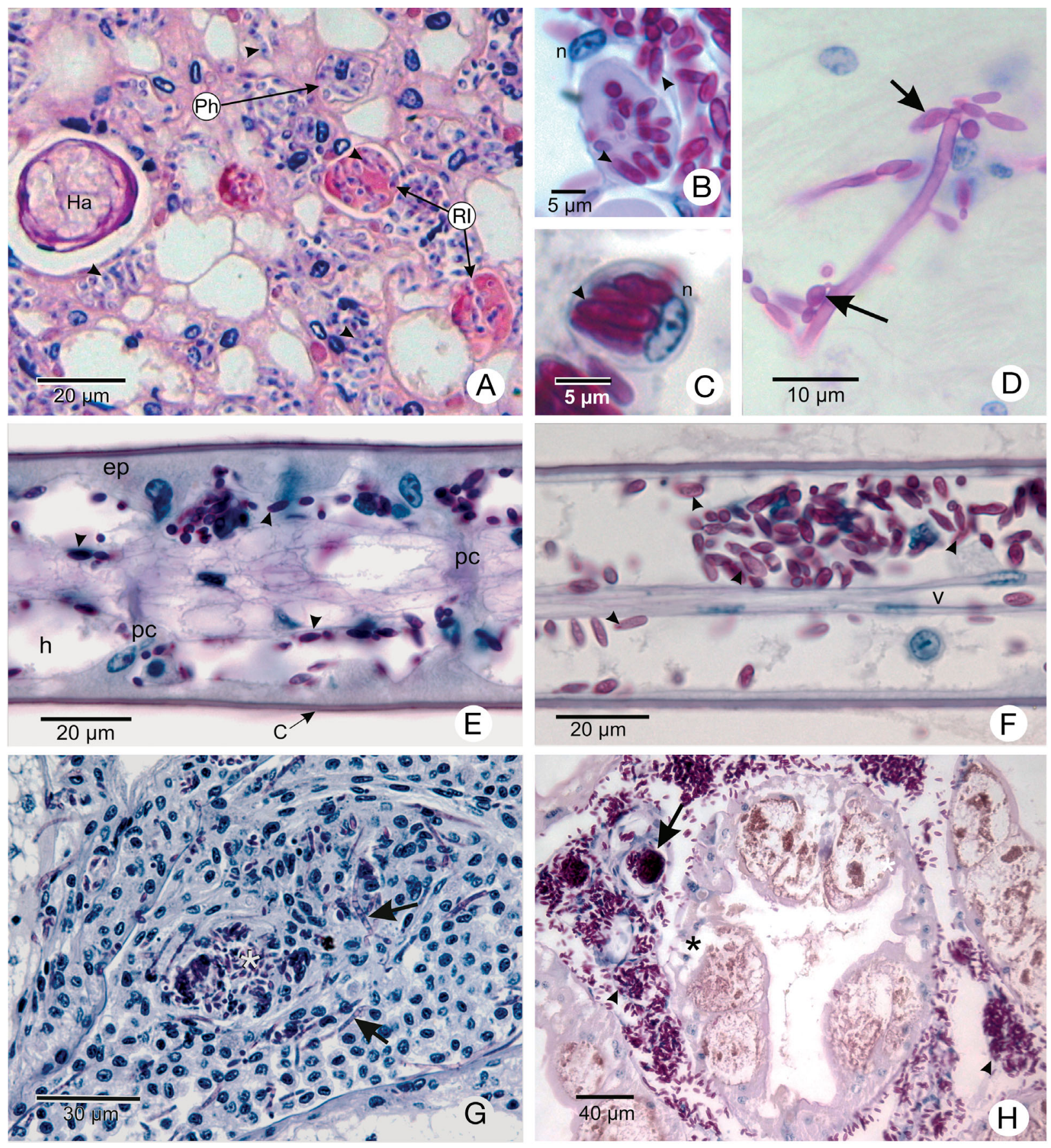

Fig. 2. Ucides cordatus infected with an Exophiala sp. and showing signs of lethargic crab disease (LCD). (A) Yeast-like cells (arrowheads) concentrated in the intersticial spaces of the connective tissue or within reserve-inclusion cells (RI), phagocytic cells $(\mathrm{Ph})$, and melanized hemocytic encapsulation (Ha). Haematoxylin and eosin (H\&E) stain. (B) RI cell with numerous yeast-like cells (arrowheads) in the connective tissue associated with the exoskeleton. $\mathrm{n}=$ nucleus of the cell. Periodic acid Schiff (PAS) and H \& E stain. (C) Phagocytic cell (probably a hyalinocyte) of the connective tissue associated with the exoskeleton with numerous yeast-like cells (arrowhead). $\mathrm{n}=$ nucleus of the cell. PAS and H\&E stains. (D) Conidiogenous hypha producing numerous conidia (arrows) in the myocardium. PAS and H\&E stains. (E) Gills of mangrove land crab with LCD in intermediate stage of infection. Although many yeast-like cells (arrowheads) are visible, most of its components are relatively intact. $\mathrm{c}=\mathrm{cuticle} . \mathrm{pc}=$ pillar cell. $\mathrm{ep}=$ epithelium. $\mathrm{h}=$ hemal lacuna. PAS and H\&E stains. (F) Gills of moribund mangrove land crab with LCD. Numerous yeast-like cells (arrowheads) are associated with the absence of most cellular components of the gills, except for the central vessel (v). PAS and H\&E stains. (G) Large haemocytic agglutination congesting the hemal sinus between tubules of the hepatopancreas, with both yeast-cells (asterisk) and hyphae (arrows). PAS and H\&E stains. (H) Yeast-like cells (arrowhead) and hemocytic encapsulations (arrow) occlude hemal sinuses of the hepatopancreas. The hepatopancreas caecum shows signs of necrosis (asterisk). 
Table 3. Ucides cordatus. Pathologies observed according to health status (Health Index) of U. cordatus

\begin{tabular}{|c|c|}
\hline Classification & Observed pathologies \\
\hline Healthy & $\begin{array}{l}\text { None-to-many hemocytic encapsulations containing yeast-like cells in gills, intestinal wall, thoracic } \\
\text { ganglion, hepatopancreas and heart. In some animals, hemocytic infiltration in heart associated with } \\
\text { hemocytic encapsulations with yeast-like cells. Abundant reserve-inclusion (RI) cells in intercecal hemal } \\
\text { spaces within the hepatopancreas. }\end{array}$ \\
\hline Intermediate & $\begin{array}{l}\text { Few-to-many hemocytic encapsulations containing yeast-like cells or hyphae (less common) in heart, } \\
\text { musculature (hemal sinuses), gills, intestinal wall, thoracic ganglion, hepatopancreas. Free yeast-like cells } \\
\text { in hemal system, heart, and thoracic ganglion. Necrosis limited to small areas within the tissue. Increase } \\
\text { in intercecal space within the hepatopancreas. Some tissue destruction in hemal lacunae of gills. Some } \\
\text { organisms may have hyphae in the heart. }\end{array}$ \\
\hline Sick & $\begin{array}{l}\text { Gills with extensive destruction of tissue within lacunae and dilation and compression of lamellae; lacu- } \\
\text { nae often obstructed with yeast-like cells. Extensive necrosis and increase in intercecal space within the } \\
\text { hepatopancreas associated with large numbers of yeast-like cells free in hemal spaces and hemocytic } \\
\text { encapsulations. Necrosis more extensive in heart (with evident disruption of muscle fibers), thoracic } \\
\text { ganglion and hepatopancreas. Occlusion of hemal sinuses by yeast-like cells in neurosecretory areas of } \\
\text { thoracic ganglion. No RI cell observed in the hepatopancreas. }\end{array}$ \\
\hline Moribund & $\begin{array}{l}\text { Hyphae and yeast-like cells abundant in all tissues. Heart with destruction or fragmentation of muscle } \\
\text { fibers. Rupture of gill lamellae observed. Extensive necrosis in hepatopancreas (often with melanization) } \\
\text { and thoracic ganglion (including neurilemma). Clusters of yeast-like cells compressing nervous fibers. } \\
\text { Great accumulation of yeast-like cells in epidermis and connective tissue associated with exoskeleton. }\end{array}$ \\
\hline
\end{tabular}

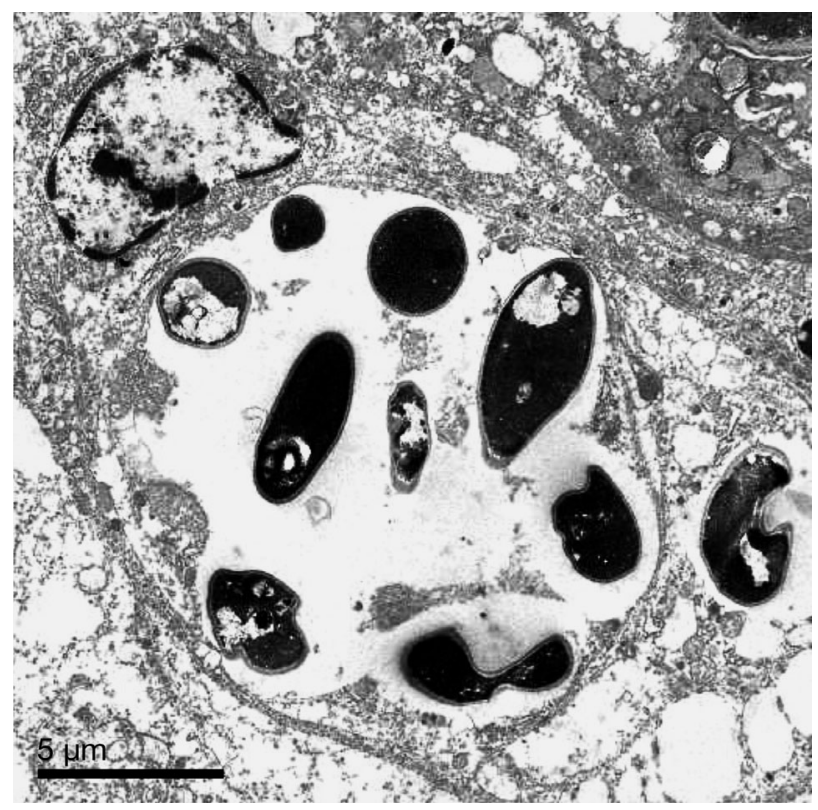

Fig. 3. Ucides cordatus. Phagocytic cell within the connective tissue associated with the exoskeleton. A large vacuole contains numerous yeast-like cells of a species of Exophiala

represent hyaline hemocytes (hyalinocytes) due to the absence of conspicuous granules in the cytoplasm (Fig. 2C). Except for tissue disorganization associated with the great accumulation of yeast-like cells in the intersticial spaces and hemal vessels, no other evident damage was detected in the epidermis and connective tissue.

\section{Gills}

Moribund mangrove land crabs usually displayed a great number of free yeast-like cells in all hemal lacunae of the gill lamellae and central shaft (Fig. 2E,F). The number of large hemocytic encapsulations containing yeast-like cells ranged from none to many, observed in crabs with or without signs of LCD.

In apparently early infections, sections of gill lamellae showed large numbers of free yeast-like cells, but little tissue damage (Fig. 2E). Epithelium, pillar cells, and hemal vessels were relatively discernible at this stage of the infection. More intense histopathologies, however, were observed in advanced infections (Fig. 2F). Pillar cells and epithelium were destroyed, yet there was no evident damage to the central hemal vessel. Dilation and reduction of the thickness of the gill lamellae were common in these advanced stages of the disease, probably a consequence of the destruction of pillar cells. Hemal pathways were often occluded by yeast-like cells and hemocytic encapsulations.

\section{Hepatopancreas}

The intercecal hemal sinuses of sick crabs were congested by a large number of yeast-like cells found within hemocytic agglutinations or encapsulations (Fig. 2G,H), or free in the hemal sinuses (Fig. 2H). Hemocytic encapsulations containing yeast-like cells were also observed in healthy crabs. Hyphae were observed less frequently and only in advanced stages 
of the infection. Heavy infections were associated with extensive degeneration of the tubules of the hepatopancreas (Fig. 2H). No fungal forms were observed within the lumen of the tubules. No RI cells were observed in heavily infected crabs.

\section{Heart}

The heart was extensively damaged by the fungal infection. Both hyphae (Fig. 4A) and yeast-like cells (Fig. 4B,C) were common, either alone or concurrently, especially in sick and moribund crabs. Infection was limited to the cardiac muscle itself with peri- and epicardia showing no signs of fungal infiltrations (Fig. 4C), even in advanced stages of LCD. Tissue disorganization (Fig. 4A-C) and extensive necrosis associated with rupture of muscle fibers (Fig. 4C) were observed. Hemocyte infiltration (Fig. 4B,C) and hemocytic encapsulation (Fig. 4A,B) were the most commonly observed host responses in this organ. Greatest tissue damage was observed when yeast-like cells were the most abundant fungal form in the organ.

Melanized and unmelanized hemocytic encapsulations, containing yeast-like cells and hyphae, were often observed in crabs with and without signs of LCD, often in large numbers (Fig. 4B). In many cases, especially in apparently healthy crabs, no free yeast-like cells were observed.

\section{Thoracic ganglion}

Both yeast-like cells and, less frequently, hyphae, were detected within the tissues and associated hemal sinuses of the thoracic ganglion of animals showing signs of LCD (Fig. 4D). The greatest concentrations of yeast-like cells and hyphae were observed outside of the ganglion complex, externally to the neurilemma. The neuroglia was the most frequently infected tissue in the ganglionar system. Infiltration of hemocytes apparently follows infection of the neuroglia, but few hemocytic encapsulations were observed in this tissue. Within the ganglia and in the neurosecretory zones (Fig. 4D,F), however, no structure associated with hemocytic response was detected.

In all tissues of the thoracic ganglion, yeast-like cells were usually found grouped, with signs of degeneration within and around the immediate vicinity of these clusters (Fig. 4F), especially in the ganglia and neuroglia. Furthermore, yeast-like cells were often observed to obstruct the hemal sinuses surrounding the neurosecretory cells (Fig. 4D) and within the ganglia. Yeast-like cells also accumulated in large clusters causing compression of nerve fibers (Fig. 4E).

\section{Other organs and tissues}

No forms of the Exophiala sp. were found within ovaries or testes. In all infected crabs, yeast-like cells were present in the hemal sinuses surrounding the gonads but were never observed within these organs. Similarly, yeast-like cells were observed solely between bundles of somatic muscular fibers. Fungi were not observed embedded within the somatic muscle fibers nor was there any evidence of damage to this tissue.

Many hemocytic encapsulations with yeast-like cells were observed within the wall of the distal portion of the intestine in sick crabs. Occasionally, yeast-like cells were observed within this tissue, causing tissue necrosis. However, numerous yeast-like cells were found in the hemal sinuses around the intestinal tissue, either free or within hemocytic encapsulations. As in the hepatopancreas, no fungal cells were observed within the lumen of the intestine.

\section{DISCUSSION}

LCD is caused by a systemic phaeohyphomycosis associated with Exophiala sp., supporting preliminary identification of the causative agent as a species of black yeast (Boeger et al. 2005). As far as we are aware, there is no similar record of mortality outbreaks of crab species in the wild caused by a species of true fungus.

No other co-occurring pathogen was consistently detected with the Exophiala sp. infection or the expression of LCD. During the examination of histological sections, we observed ciliates, rotifers and bacteria on the external surface of the gill lamellae, and digenetic trematode metacercariae encysted in the hemal sinuses of the hepatopancreas, but these were observed only sporadically. Further, besides the lack of evidence for viral infection in the histological sections, molecular diagnostic tests for a limited number of known shrimp viruses (white spot syndrome virus [WSSV], infectious hypodermal haematopoietic necrois virus [IHHNV], haematopancreatic parso-like virus [HPV], mesodermal baculovirus [MBV], Baculovirus penaei $[\mathrm{BP}]$, Taura syndrome virus [TSV], gillassociated virus [GAV] realized elsewhere; K. TangNelson \& D. Lightner pers. comm.) and experiments performed in our laboratory (authors' unpubl. data), failed to detect evidence for viral infection.

The pathology caused by the Exophiala sp. observed in the present study is compatible with the clinical signs of crabs with LCD. Infected crabs become increasingly lethargic as the disease progresses, resulting in the inability to feed or escape from predators 

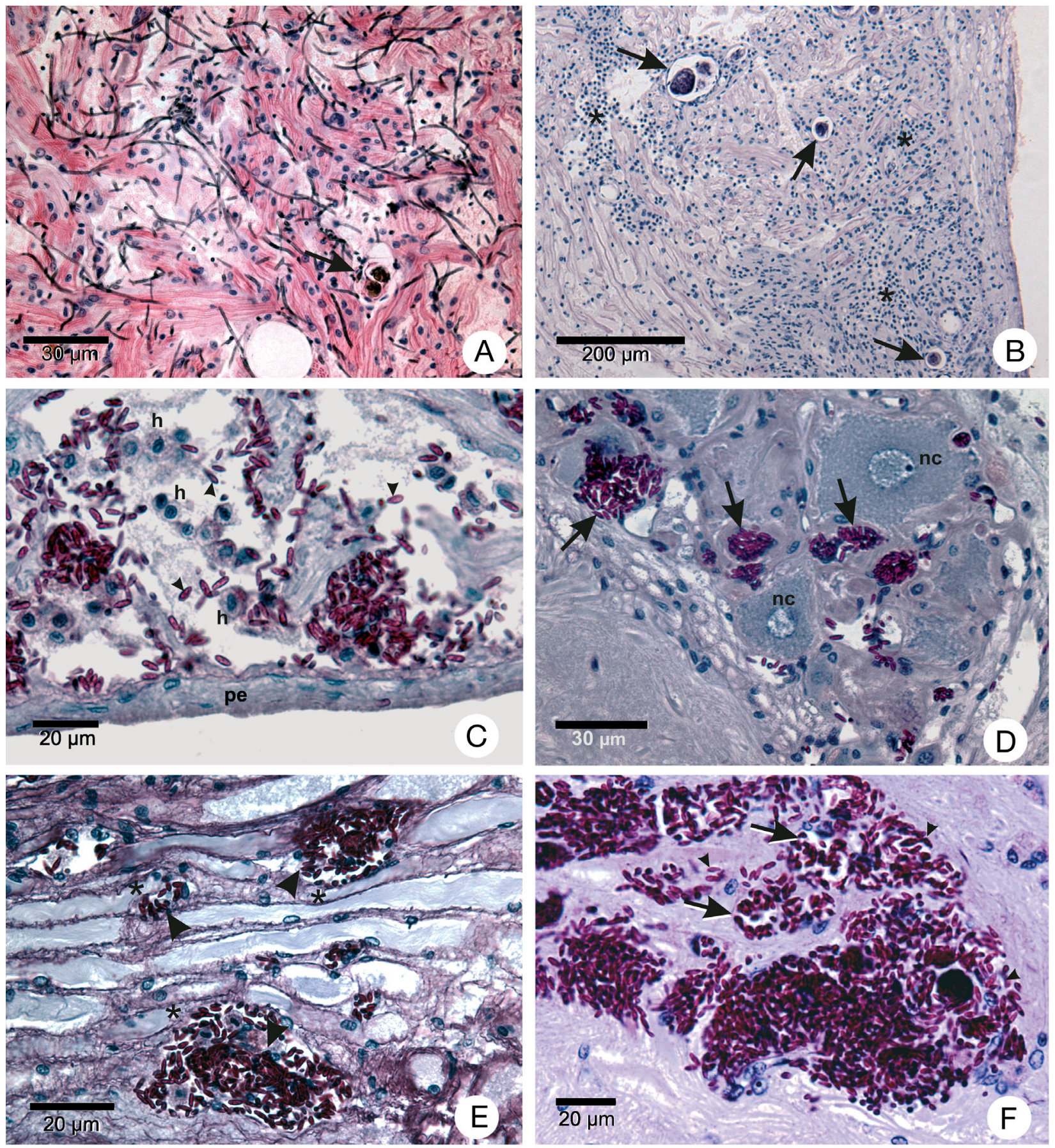

Fig. 4. Ucides cordatus infected with Exophiala sp. and showing signs of lethargic crab disease (LCD). (A) Cardiac tissue infected mostly with hyphae showing extensive tissue disorganization and hemocytic encapsulations (arrow). Grocott's methanamine silver (GMS) and haematoxylin and eosin (H\&E) stains. (B) Heart of a healthy mangrove land crab showing no gross signs of LCD. Yeast-like cells are present only within hemocytic encapsulations (arrows) and extensive infiltration of hemocytes is evident (asterisk). Periodic acid Schiff (PAS) and H\&E stain. (C) Heart of a moribund mangrove land crab with LCD. Disruption and disorganization of cardiac-muscle fibers associated with the yeast-like cells (arrowheads) with extensive hemocytic infiltration (h). Note that pericardia (pe) are free of yeast-like cells. PAS and H\&E stains. (D) Neurosecretory area of the thoracic ganglion of a moribund mangrove land crab with LCD with hemal sinuses congested by yeast-like cells (arrows). nc $=$ neurosecretory cells. PAS and H\&E stains. (E) Nerve fibers of a moribund mangrove land crab with LCD showing clusters (arrowheads) of yeast-like cells and resulting compression of some individual fibers (asterisk). PAS and H\&E stains. (F) Nerve ganglion of a moribund mangrove land crab with LCD with a large cluster of yeast-like cells (arrowheads) and associated necrosis of the tissue (arrows). 
and fishermen. Sick crabs die quickly after being captured, usually during the transfer from the mangrove and the point of commercialization. In addition, fishermen report tetany in some crabs during outbreak events. These signs strongly suggest injury to the nervous and respiratory system, as revealed in this study.

The rapid death of sick crabs, associated with capture and transport, appears to be correlated with their inability to respond adequately to corresponding stress. The obstructed hemal vessels and sinuses and the damaged heart of crabs with LCD are apparently unable to supply sufficient oxygenated hemolymph to tissues at the required rates during stress. Destruction of gill structures likely hinders gas exchange, augmenting the oxygen deficiency in these situations. Tetany is likely a consequence of the concentration of yeast-like cell clusters compressing the nerve fibers associated with the thoracic ganglion.

In nature, death of sick crabs probably occurs by an association of different factors, especially starvation, asphyxia, and cardiac failure, all consequences of the injuries caused by the fungus invading the gills, hepatopancreas, heart, and nervous system. Accordingly, the absence of RI cells in the hemal sinuses of the hepatopancreas is strong evidence for the compromised nutritional status in heavily infected crabs.

Yeast infections in crabs are uncommon. The first documented description is provided by Stentiford et al. (2003). These authors described a co-infection of a yeastlike organism and Hematodinium sp., a parasitic dinoflagellate, in 2 species of crabs from the English Channel, Cancer pagurus Linnaeus 1758 and Necora puber (Linnaeus 1767). Since no yeast-like infection was detected in Hematodinium-free crabs, Stentiford et al. (2003) initially suggested that the fungus is 'an opportunistic pathogen, possibly exploiting the weakened immune system of the host crab.' Indeed, fungal infections are often associated with the immune depression in many groups of animals, including crabs (Welsh \& Sizemore 1985, Mydlarz et al. 2006). Both primary pathogens and unsuitable environmental conditions are factors known to cause stress and subsequent weakening of the immune response of the host (Stentiford \& Feist 2005).

Evidence from this study suggests that the relative immune competence may vary among individual mangrove land crabs. Some individuals were apparently capable of impeding (at least temporarily) invasion and multiplication of the fungus within their tissues. Within some apparently healthy crabs, hyphae and yeast-like cells were found only within numerous hemocytic encapsulations and/or agglutinations. Seemingly, in other crabs, the rapid multiplication of fungal cells appears to overwhelm their immune response, resulting in the invasion and dispersion of the fungus with consequent establishment of the LCD.
Indeed, during natural mortality events of LCD in mangrove land crabs, a percentage of animals managed to survive (Nóbrega \& Nishida 2003, Schmidt 2006). A portion of these survivors likely represented crabs that were not exposed to the causative agent of LCD, but many may also have been capable of containing the invasion of tissues by the fungus. Differences in strength of the immunological response to the Exophiala sp. within a population of the mangrove land crab may be genetically, physiologically, and/or environmentally determined; the relative contribution of these factors requires further exploration.

RI cells of the connective tissue associated with the exoskeleton of infected crabs contained large numbers of yeast-like cells. While this could represent an infection at the cellular level by the yeast-like cells, the absence of similar or other cell types containing large amounts of yeast-like cells in other tissue examined in the present study strongly supports the suggestion of Fontaine \& Lightner (1975) that these cells (called 'basophilic cells' in their publication) are indeed capable of phagocytosis. Besides RI cells, heavily infected crabs have large numbers of other phagocytic cells within this same connective tissue. They probably represent mobile cells of the hemolymph (probably hyalinocytes) that infiltrated into this tissue and incorporate large numbers of yeast-like cells into a large internal vacuole. This connective tissue was the only studied tissue presenting such phagocytic cells.

The large number of yeast-like cells within the hemal sinuses and vessels strongly indicates that they play an important role in the systemic dispersion of the Exophiala sp. into different tissues and organs. Yeastlike cells were found initially within the hemal spaces and vessels of each organ in apparently early infections that later invade other organs and systems (i.e. heart, nervous system, epidermis). The absence of fungal forms within the lumen of the digestive tract is not consistent with feeding as a pathway for the infection, although we cannot completely eliminate this possibility since contamination may be sporadic. We postulate that either the gills or damaged areas of the exoskeleton and of the intersegmental membranes are candidates for the site of invasion by the fungus, particularly during ecdysis, but this requires specific experimentation.

Acknowledgements. Financial support for this study was provided by the Companhia de Desenvolvimento Industrial e de Recursos Minerais de Sergipe (CODISE), the Secretaria de Estado da Ciência, Tecnologia e Ensino Superior do Estado do Paraná (SETI) and the Conselho Nacional de Desenvolvimento Científico e Tecnológico (CNPq), Brazil. S. C. de Hoog, Centraalbureau voor Schimmelcultures, Netherlands, confirmed the preliminary identification of the fungus species. 
He and J. Shields, Virginia Institute of Marine Sciences, USA, provided important suggestions during development of the study. W.A.B. is a research fellow of CNPq.

\section{LITERATURE CITED}

Boeger WA, Pie MR, Ostrensky A, Patella L (2005) Lethargic crab disease: multidisciplinary evidence supports a mycotic etiology. Mem I Oswaldo Cruz 100:161-167

De Hoog, GS, Vicente V, Caligiorne RB, Kantarcioglu S, Tintelnot K, Gerrits van den Ende HG, Haase G (2003) Species diversity and polymorphism in the Exophiala spinifera clade containing opportunistic black yeast-like fungi. J Clin Microbiol 41:4767-4778

Fontaine CT, Lightner DV (1975) Cellular responses to injury in penaeid shrimp. Mar Fish Rev 37:4-10

Glaser M (2003) Ecosystem, local economy and social sustainability: a case study of Caeté estuary, North Brazil. Wetlands Ecol Manag 11:265-272.

Humason GL (1979) Animal tissue techniques, 4th edn. WH Freeman \& Company, San Francisco, CA

Mydlarz LD, Jones LE, Harvell CD (2006) Innate immunity, environmental drivers, and disease ecology of marine and freshwater invertebrates. Annu Rev Ecol Evol Syst 37: 251-88

Nóbrega, RR, Nishida AK (2003) Aspectos socioeconômicos e percepção ambiental dos catadores de caranguejo-uçá,

Editorial responsibility: Timothy Flegel,

Bangkok, Thailand
Ucides cordatus (L.1763) (Decapoda, Brachyura) do estuário do rio Mamanguape, Nordeste do Brasil. Interciência 28:36-43

Rasband W (2006) Image J. Research Services Branch, National Institute of Mental Health, Bethesda, MD. Available at: http://rsb.info.nih.gov/ij/docs/index.html

Schmidt A (2006) Estudo da dinâmica populacional do caranguejo-uçá, Ucides cordatus cordatus (LINNAEUS, 1763) (CRUSTACEA-DECAPODA-BRACHYURA), e dos efeitos de uma mortalidade em massa desta espécie em manguezais do Sul da Bahia. MSc thesis, Instituto Oceanográfico, Universidade de São Paulo

Schories D, Barletta-Bergan A, Barletta M, Krumme U, Mehlig U, Rademaker V (2003) The keystone role of leafremoving crabs in mangrove forests of North Brazil. Wetlands Ecol Manag 11:243-255

Stentiford GD, Feist SW (2005) A histopathological survey of shore crab (Carcinus maenas) and brown shrimp (Crangon crangon) from six estuaries in the United Kingdom. J Invertebr Pathol 88:136-146

Stentiford GD, Evans M, Bateman K, Feist SW (2003) Coinfection by a yeast-like organism in Hematodiniuminfected European edible crabs Cancer pagurus and velvet swimming crabs Necora puber from the English Channel. Dis Aquat Org 54:195-202

Welsh PC, Sizemore RK (1985) Incidence of bacteremia in stressed and unstressed populations of the blue crab, Callinectes sapidus. Appl Environ Microbiol 50:420-425

Submitted: November 28, 2006; Accepted: July 4, 2007 Proofs received from author(s): October 15, 2007 